\title{
Underground Spaces: a Step Towards Sustainable Development in Khuzestan Province, Iran
}

\author{
Wykorzystanie podziemi: krok w kierunku \\ zrównoważonego rozwoju w prowincji Chuzestan w Iranie
}

\author{
Sohrab Ghaedi \\ Shahid Chamran University of Ahvaz \\ Ahvaz, Khuzestan province, Iran, 6137873396, \\ E-mail: S.ghaedi@scu.ac.ir, ORCID: 0000-0002-4016-6342
}

\begin{abstract}
Reducing the consumption of fossil fuels using the underground spaces has a significant impact on the economic, social and environmental dimensions of sustainable development. In this study, the temperature of soil layers and the thermal comfort in these layers were investigated to create the underground spaces in Khuzestan province. The average summer temperature in the center of the province is about $38^{\circ} \mathrm{C}$, which is far from the comfort of the temperature. The surface annual temperature fluctuation in the province varies from 23.5 in the north of the province to $28.5^{\circ} \mathrm{C}$ in the southeast. Investigating the temperature fluctuation in the soil layers shows that it decreases by increasing the depth, so that at a depth of 10 meters, the temperature fluctuation is approximately zero which is equal to the annual average temperature. Therefore, up to a depth of $10 \mathrm{~m}$, temperature fluctuation decreases by increasing the depth. The use of underground spaces in the province can be ta-ken as an alternative in coping with heat and extreme sunlight, reducing energy and controlling dust. It also has a positive effect on economic, social, and environmental dimensions of sustainable development.
\end{abstract}

Key words: underground space, temperature fluctuation, soil depth temperature, comfort thermal, Khuzestan province

\section{Streszczenie}

Zmniejszenie zużycia paliw kopalnych z wykorzystaniem przestrzeni podziemnych ma znaczący wpływ na wymiar gospodarczy, społeczny i środowiskowy zrównoważonego rozwoju. W tym badaniu zbadano temperaturę $\mathrm{i}$ komfort cieplny warstw gleby w tych warstwach, aby stworzyć podziemne przestrzenie w prowincji Chuzestan. Średnia temperatura latem w centralnej części prowincji wynosi około $38^{\circ} \mathrm{C}$, co jest dalekie od komfortowej temperatury. Roczne wahania temperatury powierzchniowej w prowincji wahają się od $23,5{ }^{\circ} \mathrm{C}$ na północy prowincji do $28,5^{\circ} \mathrm{C}$ na południowym wschodzie. Badanie wahań temperatury w warstwach gleby wykazało, że zmniejsza się ona wraz ze wzrostem głębokości, tak że na głębokości 10 metrów wahania temperatury są w przybliżeniu zerowe i są równe średniej temperaturze rocznej. Dlatego do głębokości $10 \mathrm{~m}$ wraz z rosnącą głębokością zmniejszają się wahania temperatury. Wykorzystanie przestrzeni podziemnych w tej prowincji może być wykorzystane do walki z upałem i ekstremalnym nasłonecznieniem, ograniczania zużycia energii i kontrolowania zapylenia oraz ma pozytywny wpływ na wymiar ekonomiczny, społeczny i środowiskowy zrównoważonego rozwoju.

Słowa kluczowe: podziemia, zmiany temperatury, temperatura głębi ziemi, komfort termiczny, prowincja Khuzestan 


\section{Introduction}

The impact of environmental conditions on life and activity of human is not overlooked by anyone, and the climate is more influential than other factors; therefore human comfort depends on suitable climate conditions (Barradas, 1991; Schell et al., 2009). Today, study the impact of climate on the life, health, comfort, and behavior of human is studied as one of the branches of climate by name of human bioclimatic (Givoni, 1976; Vanos et al., 2010; Ghaedi, 2019). Human has always sought to create suitable spaces that would provide him comfort with the least energy, including the underlying layers of the soil. Living in underground spaces has a long period of human history and this returns to the habitation in the caves and before the modern technology leads to the construction of the usual buildings on the ground (Reddy, 2003; Fardpour, 2013). The underground architecture is rooted in traditional Iranian architecture, is the answer to the problem of human interaction with the environment (Khaki and Sadat, 2015). Iranian art and architecture has long had some principles that have been well illustrated in its samples. These principles are as follows: Humanization, Avoiding Non-essential, Stability, Self-Sufficiency and Inward-looking (Khodabakhshian and Mofidi Shemirani (2014). In arid regions, buildings are constructed with introverted styles, and they try to place the building in the ground and enclose the entire building from four sides, which the buildings are built in four geographic directions and around a central courtyard, are known as the Four Seasons Houses, to create a comfort climate in the residential spaces of these regions (Khodabakhshian, 2013; Soflaei et al., 2017). In warm and dry regions of Iran people to avoid from extreme and severe weather in the warm and cold seasons, Due to low rainfall and dry weather, and also in order to protect from dust caused by extreme winds, refuge to the underground spaces (Rahmani, 2013; Roshan et al., 2018). Khuzestan province is one of the important poles of agriculture and industry in the country. The low elevation in most regions of the province, situation near the vast deserts of Iraq and Saudi Arabia and extreme winds from these areas, the low latitude and establishment of high pressure subtropical over the long period in warm season, have caused very high temperatures in most parts of the province, as maximum temperatures reach about $50{ }^{\circ} \mathrm{C}$ in most regions. Investigating the bioclimatic indicators in the province shows that in the most period of spring and throughout the summer, there aren't comfort conditions in the province; but at other times more comfortable conditions prevail in the province (Daneshvar et al., 2013). The long period of heat in the Khuzestan plain has forced inhabitants to thinking the use of underground spaces for the shelter under layers of soil to avoid from unfavorable weather conditions, includ- ing Shavadoon in Dezful and Shushtar and ventilation channel called Tal (Hazbei et al., 2014; Sadooghi et al., 2019). Nowadays, however, these places have been lost or even destroyed due to the use of new heating and cooling technologies. The cheap energy generated from the vast oil and gas resources in Iran It has largely avoided nature-based construction methods. Underground spaces, in addition to provide thermal comfort, from the emotional aspect they also causes mental relaxation, reduction of stress and thinking. In addition to the above, underground construction according to the principles of sustainable development has other function such as: decreasing of environmental stresses, energy saving (Asadi et al., 2016), Increasing various efficiency in urban structure, reducing the need to local transportation, facilitating and improving public services and the preservation of urban landscapes and cultural heritage. What justifies the use of underground spaces in Khuzestan province, in addition to protect from extreme heat, is safe from dust and decreasing of energy consumption. The climate is one of the most important factors affecting human life, which is not always ideal and stable. This variability and unsuitable has made human to use places with more consistent and appropriate conditions. Underground architecture has created this suitable condition for mankind. Although the creation of settlements in the underground will solve the problem of extreme temperature variability, it also has other advantages and disadvantages. Table 1 provides an overview of the advantages and disadvantages of using underground spaces that have been surveyed in aspects of economic, technical, functional, social and environmental (Ronka, 1998).

\section{Sustainable development and Underground spaces}

First in 1980, the International Union for Conservation of Nature and Natural Resources (IUCN) was proposed the term sustainable development. Today, this concept is applied to planning, architecture and urban design in the framework of urban policy and development (Williams et al., 2000). Overall, sustainable development is Meeting the present needs of human society so as not to compromise the ability of the future generation to meet their needs. According to the definition of sustainable development, it has 3 basic pillars, including environmental, economic and social factors. The most important features of underground spaces from the perspective of sustainable development are:

1- climate: decreasing temperature fluctuations in underground spaces provides the conditions for reducing energy consumption.

2- health: Underground spaces provide relaxation and reduce stress by reducing the noise, pollution and visual clutter. 
Table 1. Selection of advantages and disadvantages of underground spaces

\begin{tabular}{|c|c|c|}
\hline Aspects & Advantages & Disadvantages \\
\hline Economic & $\begin{array}{l}\text { Possibility to create compact urban structure and tex- } \\
\text { ture } \\
\text { Ability to save on secondary land use (traffic, Park- } \\
\text { ing) for recreational, business and residential space } \\
\text { use } \\
\text { The bed stone can be used for heating and cooling }\end{array}$ & $\begin{array}{l}\text { In loose soils, surface joints (portals and columns) may } \\
\text { significantly increase the cost of underground construc- } \\
\text { tion }\end{array}$ \\
\hline Technical & On hard land is affordable & In the loose soils, surface joints are damaged \\
\hline Functional & $\begin{array}{l}\text { The new streets do not intersect with each other } \\
\text { Urban transport becomes safer }\end{array}$ & $\begin{array}{l}\text { The probability of creating a problem to coordination } \\
\text { with the surface transport network }\end{array}$ \\
\hline Social & $\begin{array}{l}\text { The quality of life in urban centers increases with the } \\
\text { transfer of transport networks into the ground }\end{array}$ & $\begin{array}{l}\text { Reduced control of underground spaces (tunnels, park- } \\
\text { ing) } \\
\text { The underground navigation is difficult }\end{array}$ \\
\hline Environmental & $\begin{array}{l}\text { Underground structures help preserve natural land- } \\
\text { scapes and protect urban areas. } \\
\text { Underground construction does not affect the city's } \\
\text { landscape or the natural conditions of the area } \\
\text { Environmental tensions (such as noise pollution) can } \\
\text { be reduced by underground construction } \\
\text { Underground construction helps preserve environ- } \\
\text { mental and cultural values }\end{array}$ & $\begin{array}{l}\text { Underground structures may reduce groundwater levels } \\
\text { Job satisfaction in closed spaces is generally less than } \\
\text { the available space on the ground } \\
\text { Locating suitable for ramps and other underground } \\
\text { spaces is difficult with connection points on the surface. }\end{array}$ \\
\hline
\end{tabular}

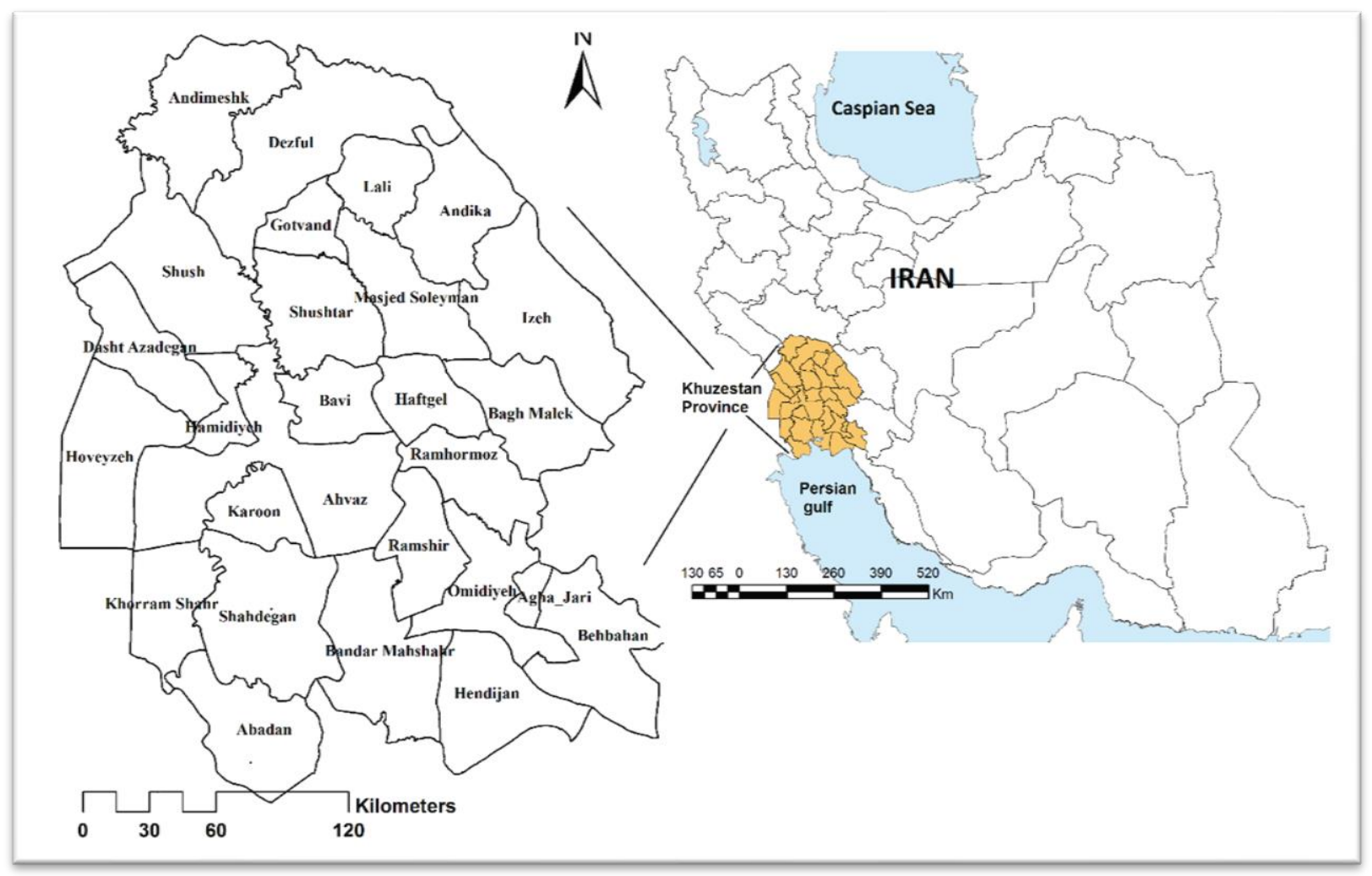

Figure 1. The location of the study area

3- softy: Underground spaces are safer from fire, earthquake and adverse weather conditions.

4- Increasing green space and consumption from the environment: The use of subsurface spaces provides more space for green space.
5- Solve the problem of shortage of urban land: One of the main problems of cities, especially in the centers, is the shortage of land for various uses such as commercial, transportation, infrastructural and residential. 
Due to the fact that the very high temperature of the province affects all biological conditions and dimensions of development, and on the other hand, underground spaces provide suitable temperature conditions for residents, so in this paper, first the temperature conditions in the soil layers are evaluated and then the effect of this is surveyed on the dimensions of sustainable development.

\section{Study area and data}

Khuzestan Province is located in the southwest of Iran and lies between $29^{\circ} 56^{\prime}$ and $33^{\circ} 5^{\prime}$ northern latitude and $37^{\circ} 47^{\prime}$ to $26^{\circ} 50^{\prime}$ eastern longitude with a total surface area of $64057 \mathrm{~km}^{2}$. Most of the province area is a platform or continental shield and these flat area are limited to the Zagros Mountains from north, northeast, and east (Dehcheshmeh and Ghaedi, 2020). To zoning and determination of the temperature in different layers of the soil, was used the monthly temperature data from 17 stations in the province. The temperature data was applied between January 1988 and December 2017 recorded by the I.R. of Iran Meteorological Organization (IRIMO). Figure 1 shows the position of the stations in this study.

\section{Method of calculating the temperature of the subsoil layers}

The heat is transmitted from the surface to the soil by a sinusoidal model.

$\mathrm{T}^{\prime}{ }_{\mathrm{x}}=\mathrm{T}_{\mathrm{m}}-\mathrm{A}_{\mathrm{s}}\left(\mathrm{e}^{-\mathrm{xr}}\right) \cos \left[\frac{360}{365}\left(\mathrm{t}-\mathrm{t}_{\mathrm{o}}-\mathrm{xL}\right)\right]$

$\mathrm{T}^{\prime}{ }_{\mathrm{x}}$ is here the temperature at a depth of $\mathrm{x}(\mathrm{F})$, $\mathrm{x}$ depth (feet), $\mathrm{T}_{\mathrm{m}}$ mean annual temperature $(\mathrm{F})$, e Euler's number is approximately equal to $2.71828, \mathrm{r}$ log reduction (square feet), L time delay (day / Ft), $\mathrm{A}_{\mathrm{s}}$ The amount of annual fluctuation of solar radiation on the horizontal surface (day / ft.), t time of the year which is calculated from January $1 \mathrm{st}, \mathrm{t}_{\mathrm{o}}$ fixed day, $365 / 360$ converts 365 calendar days to 360 degrees. To calculate the temperature log reduction in per square foot of soil (r), the following equation is used.

$r=\sqrt{\frac{\pi}{365 a}}$

a is thermal scattering, which is the result of the heat conduction (k) divided by the thermal capacity (c).

Since heat conduction and thermal capacity change with the amount of soil moisture, it is difficult to calculate them. Therefore, the annual amount of (a) is calculated for dry (0.33), moderate $(0.52)$ and wet situation (0.75) square feet per day. Therefore, the value of $r$ would be $0.1615,0.12865$ and 0.10713 respectively, and the values of $\mathrm{L}$ would be equal to $9.38,7.47$ and 6.22 , respectively, although the time delay (L) from the following equation also Comes:

$\mathrm{L}=0.5 \sqrt{\frac{365}{\pi \mathrm{a}}}$
The thermal model is correct only assuming the soil is homogeneous at that depth and when the heat conduction is carried out by conduction. It is not accurate, especially when the ground is covered by snow or the groundwater temperature variations are high. The simpler form of the first equation can be used and is more suitable, especially when the air temperature and the land surface temperature are the highest.

$\mathrm{T}^{\prime}{ }_{\mathrm{x}}=\mathrm{T}_{\mathrm{m}}+\mathrm{A}_{\mathrm{s}}\left(\mathrm{e}^{-\mathrm{xr}}\right) \cos (\mathrm{XL})$

$\mathrm{XL}$ is the time delay to the degree (conversion coefficient 365/360, which can be ignored).

\section{Results and discussion}

5.1. Average seasonal temperature of the province A factor Analysis on climate data shows that the most important factor in the Khuzestan province is the thermal (Movahedi et al. 2012); Therefore, the temperature plays a decisive role in the climatic conditions of the province. Figure 2 presents the average temperature of four seasons of the province by the isothermal curves. In the spring, the average temperature in the central regions of the province is $33^{\circ} \mathrm{C}$, which is actually the maximum temperature observed in the province, and the lowest temperature is about $20^{\circ}$ in the northeast. In the summer and autumn conditions are the same and the highest temperature belongs to the central regions of the province $\left(38^{\circ} \mathrm{C}\right.$ in the summer and $22^{\circ} \mathrm{C}$ in the autumn). In these seasons in the southern regions, due to its proximity to the Persian Gulf and the latent heat of evaporation, the maximum temperature is not seen in the southern regions. In the winter, the warm waters of the Persian Gulf moderate the climate conditions in the south and observe the highest temperatures in these regions $\left(17^{\circ} \mathrm{C}\right)$. In summer, the average temperature in the central regions reaches to $38^{\circ} \mathrm{C}$ that is severe temperature. In the autumn in the central regions, the average temperature is reduced to $22^{\circ} \mathrm{C}$, which shows $16^{\circ}$ negative fluctuations compared to summer. The warm season in Khuzestan has a long period and lasts from May to mid-November. Then, with a short-term transition period until mid-December, the cold season begins, which lasts until the end of February. March can be called the beginning of Khuzestan spring, which is followed in April, although the temperature rises, but the climate is still favorable.

\subsection{The temperature fluctuations in subsoil layers}

Figure 3 shows the temperature fluctuations in different depths of the earth relative to the annual average. At the earth surface, the highest fluctuation is related to the north of the province with a mean value of $28.5^{\circ} \mathrm{C}$. This value reaches to $23.5^{\circ} \mathrm{C}$ in the south east, which indicate 5 degrees decreasing. At one meter depth, the temperature fluctuation decreases suddenly $7^{\circ} \mathrm{C}$ in the north of the province and its 

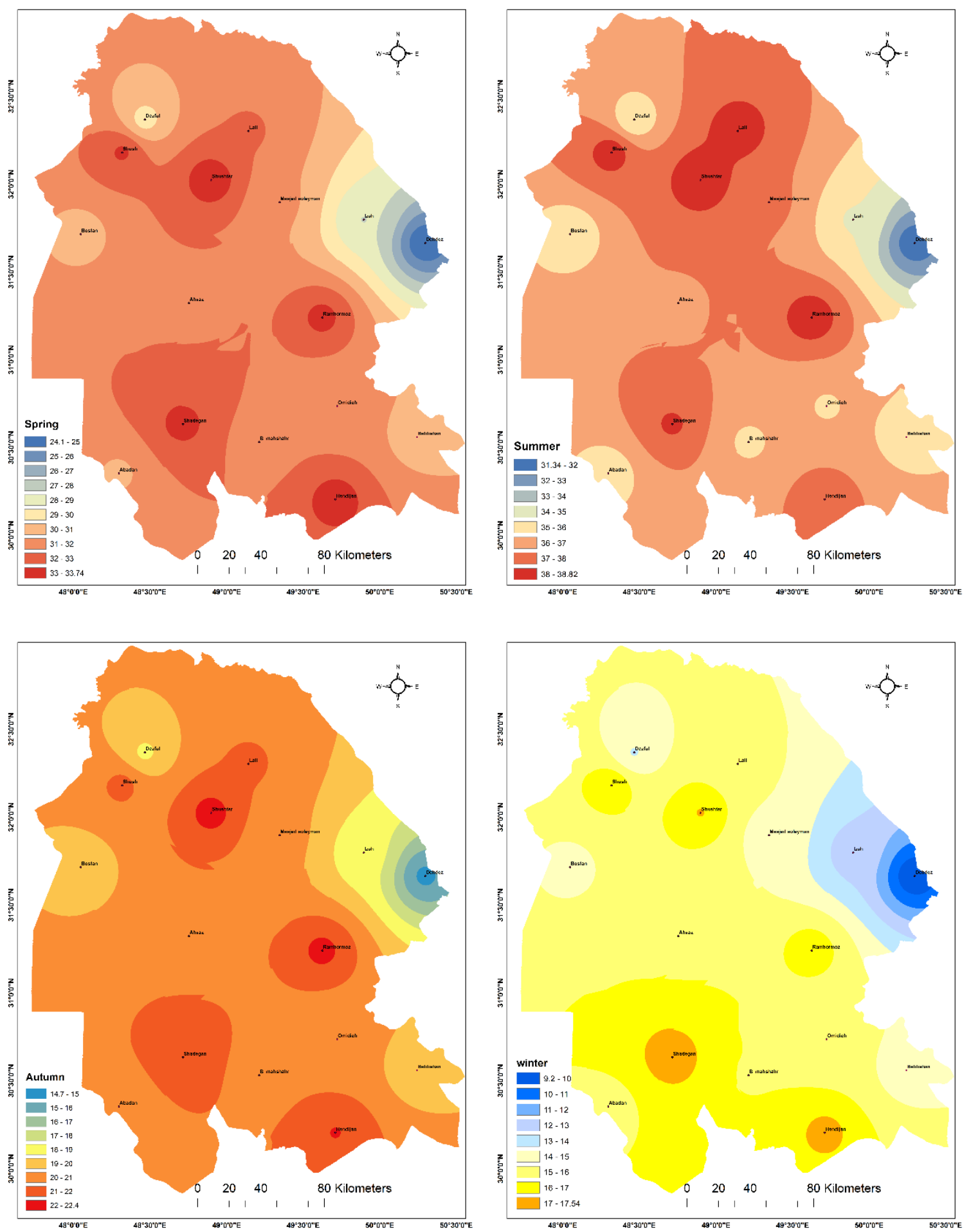

Figure 2. Average seasonal temperature of the province

value reaches $21.5^{\circ} \mathrm{C}$ and this is about $20^{\circ} \mathrm{c}$ in the south east. At three meters depth, the temperature has very severe fluctuation that shows $9.3^{\circ} \mathrm{c}$ in the north and $8.7^{\circ} \mathrm{C}$ in the south-east. At five meter depth, the oscillation is $4^{\circ} \mathrm{C}$ in the north, which does not show much difference with the southern regions with a value of $3.7^{\circ} \mathrm{C}$.

\subsection{The average annual temperature of the prov- ince}

The $1.72^{\circ} \mathrm{C}$ fluctuation at seven meter depth is related to the north of province, which is slightly lower in the southeast that is $1.6^{\circ} \mathrm{C}$. At 9 meter depth, the temperature fluctuates in throughout of the province is less than $1^{\circ} \mathrm{C}$ and varies between $0.74^{\circ}$ in the north to $0.69^{\circ} \mathrm{C}$ in the south regions. 

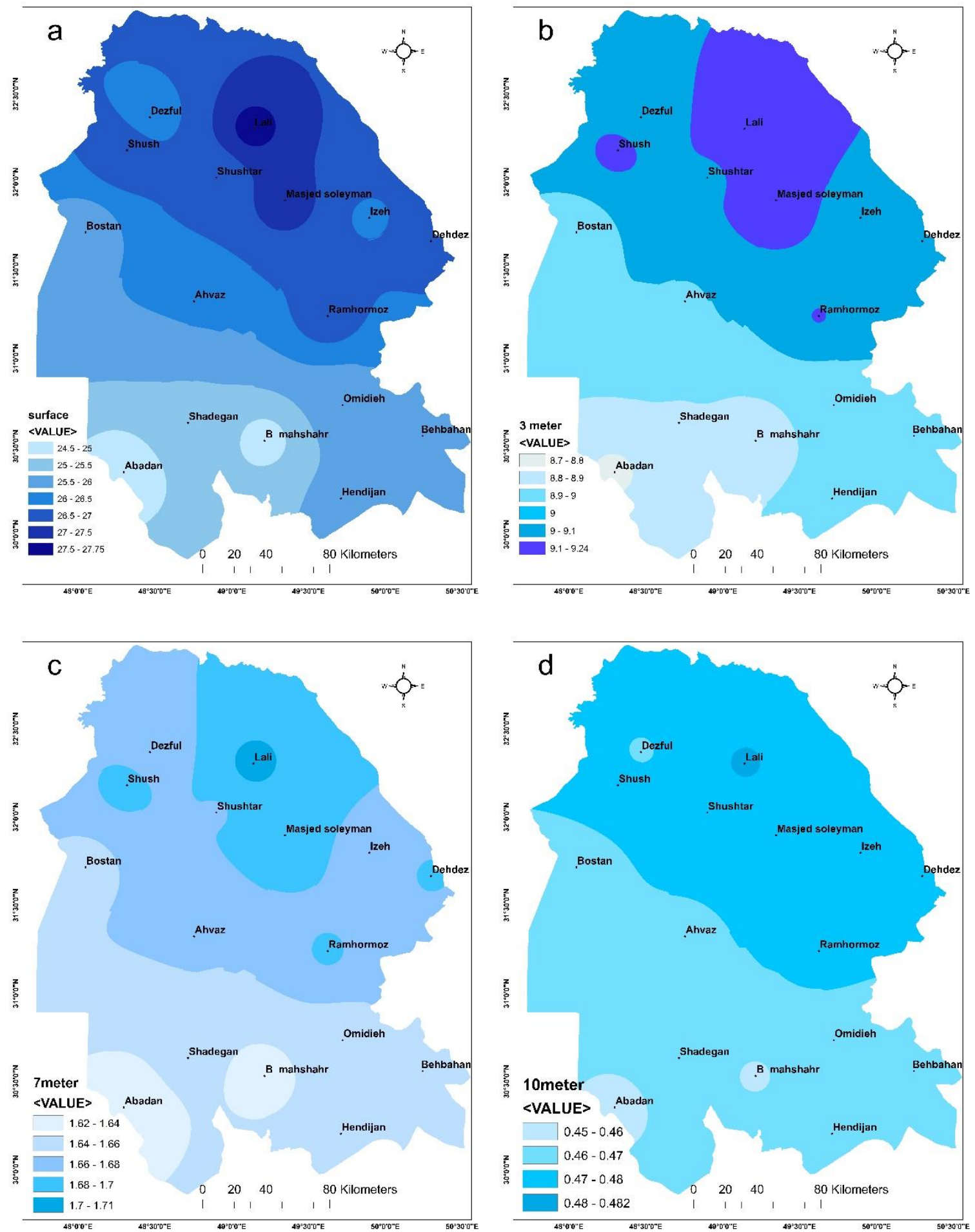

Figure 3. The temperature fluctuations in subsoil layers, surface (a), 3 meter (b), 7 meter (c), 10 meter (d)

From the ten meter depth, the temperature fluctuates approximately is zero, and therefore the temperature in this depth is approximately equal to the annual average.

The average annual temperature of the province is presented in figure 4, which is approximately equal to the temperature of the soil layers at more than 10 meter depth. In the vast range of northwest to south- east provinces, the average temperature is $26^{\circ}$ to $27^{\circ}$ $\mathrm{C}$, which is reduced to the northeast (toward Zagros Mountains) and ultimately reaches to $15^{\circ} \mathrm{C}$. Physiologically, thermal comfort conditions is a range of humidity and temperature that the body human mechanism has the least activity to regulating itself. Different factors affect thermal comfort, such as temperature, humidity, air flow, mean radiant 


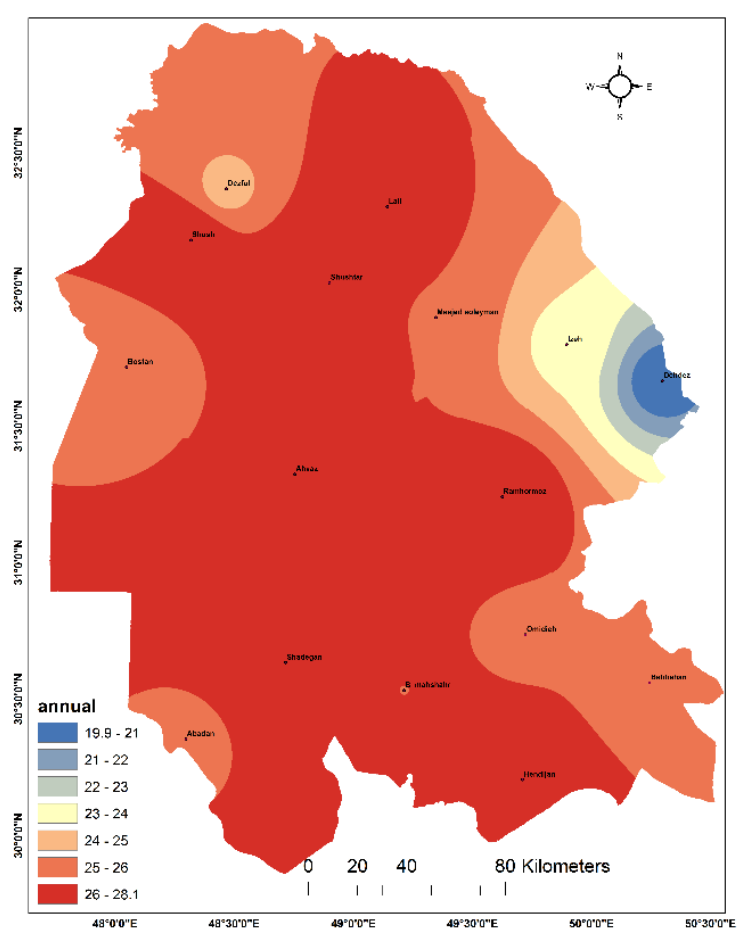

Figure 4. The average annual temperature of the Khuzestan province

temperature, physical activity level and the amount of clothing cover. The indices used to determine thermal comfort also vary widely that are considered with respect to various variables. In the lower layers of soil, the most important factors are temperature and humidity, because sun radiation and air flow are deleted, and the amount of activity and coverage is very different and it's in human control. The amount of humidity is also very variable and it depends on the soil moisture. Therefore, more than anything else should be considered to the temperature factor in the lower layers of soil. In different regions of the world, depending on different conditions and factors, different thermal comfort are considered for the temperature range, most of which are between 19 and $27^{\circ} \mathrm{C}$. Of course, besides the temperature factor, humidity should also be considered that is very effective in adjusting the temperature values. Since most areas of the province show an average annual temperature of 26 to $27^{\circ} \mathrm{C}$, therefore, there are thermal comfort condition in more than 10 meters depth and if people feel uncomfortable, partial ventilation can be created. Low elevation and plain conditions have caused high groundwater levels in the most of the Khuzestan province, especially in the southern half. These conditions are exacerbated on the Persian Gulf Coast, along the banks of rivers, marshes and lagoons in the province. Periodic changes in water level and measuring water levels outside the cities has led to a lack of a comprehensive groundwater level map in urban areas. However due to the importance of water level in the cost and durability of underground structures, it is necessary to investigate the water level before taking any action in creating underground spaces.

\subsection{The impact of underground spaces on sus- tainable development pillars in Khuzestan province:}

The essential pillars of development are society, economy and environment factors, and the sustainable development of a region is the overlapping of these pillars (Sobczyk, 2015). Underground spaces affect each of these factors, and the result of these interactions leads to sustainable development in an area.

- Economic effects of underground spaces: the long - term high temperature in Khuzestan province (April to November), which shows temperatures above $50^{\circ} \mathrm{C}$ in summer, necessitates the use of cooling systems. The cost of supplying, maintaining and powering these systems in the province is very high. Decreasing ambient temperature by underground spaces reduces the need for these systems (Chovancová and Vavrek, 2019). In addition, must also be considered the costs of health, fire, earthquake, etc.

- Environmental: Some of the effects of underground spaces on the environment are: Reduce environmental pollution as a result of reduced energy consumption, more surface green space, Preserving environmental and cultural values, reduced traffic, preserving natural landscapes and protect urban areas, Environmental tensions.

-social: In terms of social dimension, several physical (Social justice, Health, quality of life and wellbeing, Cultural traditions, Residential stability, Safety, etc.) and non-physical factors (Decent housing, Attractive public realm, Local environmental quality and amenity, Sustainable urban design, Accessibility to local services, Urbanity, etc.) can be considered in the concept of sustainable development. Due to the advantages of underground spaces in Table 1, it can be said that these spaces improve social conditions. However, in some factors such as (Social interaction, neighborhood, Active community organizations, Walkable neighborhood, etc.) underground spaces need further investigation (Dempsey et al, 2009).

\section{Conclusion}

Khuzestan province that is one of the focal points of human civilization, today is one of the economic and demographic poles of Iran with the benefit of water resources, soil and fossil energy. In most parts of the province, the low elevation and impact of subtropical high pressures during the warm season cause extremely high and sometimes unbearable temperatures. Therefore, in summer the average temperature reaches more than $36^{\circ} \mathrm{C}$ and the maximum temperature sometimes exceeds $50^{\circ} \mathrm{C}$. In these unfavorable temperature conditions, the use of cooling devices increases the energy consumption. This in turn leads to positive feedback, and as a result, the environment 
temperature increases. Therefore, adjusting the environmental conditions will increase the thermal comfort and reduce energy consumption. One of the effective ways to create favorable environmental conditions is the use of underground spaces, or earth sheltered architecture, which has long been used in different parts of the world including Iran. The thermal Insulating characteristics of the soil decrease soil temperature fluctuation with increasing soil depth and soil temperature close to the average annual air temperature. In this study, the annual soil temperature fluctuation was evaluated for different depths in the Khuzestan province. The highest temperature fluctuation is related to the soil surface in the north of the province about $28.5^{\circ} \mathrm{C}$, which decreases to the southeast and reaches $23.5^{\circ} \mathrm{C}$. At one meter depth, the temperature fluctuation decreases $7^{\circ} \mathrm{C}$ in the north of the province and reaches $21.5^{\circ}$ C. This value is about $20^{\circ} \mathrm{C}$ in the southeast. At three meter depth, the temperature fluctuates with a steep drop, is indicating a value of $9.3^{\circ} \mathrm{C}$ in the north and $8.7^{\circ} \mathrm{C}$ in the southeast. At five meter depth, this value is $4^{\circ} \mathrm{C}$ in the north of the province, which is not very different from the southern areas that is $3.7^{\circ} \mathrm{C}$. In the seven-meter depth, the highest fluctuation is related to the north of the province $\left(1.72^{\circ} \mathrm{C}\right)$ that is slightly lower in the southeast $\left(1.6^{\circ}\right.$ C). At 9 meter depth, the temperature fluctuations are less than $1^{\circ} \mathrm{C}$ in the entire of the province and it varies between 0.74 in the south to $0.69^{\circ} \mathrm{C}$ to the southern regions. From ten meter depth, the temperature fluctuation is about zero ${ }^{\circ} \mathrm{C}$, so the temperature at this depth is approximately equal to the annual average. The highest average annual temperature in the province is related to central regions $\left(27^{\circ} \mathrm{C}\right)$ that it is decreased in other areas, especially in the northeast. Therefore, temperature in more than 10 meter depth are almost within the thermal comfort zone and can be get to the ideal state conditions with little ventilation in most areas of the province. The occurrence of climate change increases the importance of Earth Sheltered architecture in the future (IPCC, 2014). Due to the climatic conditions of the province and global warming, the use of underground spaces can affect various economic, environmental and social dimensions and thus achieve the goals of sustainable development in the province.

\section{References}

1. ASADI S., M. FAKHARI M., SENDI M., 2016, A study on the thermal behavior of traditional residential buildings: Rasoulian house case study, in: Journal of Building Engineering 7(1), p. 334-342.

2. BARRADAS V. L., 1991, Air temperature and humidity and human comfort index of some city parks of Mexico City, in: International Journal of Biometeorology 35(1), 24-28.

3. CHOVANCOVÁ J., VAVREK R., 2019, Decoupling Analysis of Energy Consumption and Economic Growth of V4 Countries, in: Problemy Ekorozwoju/ Problems of Sustainable Development, 14(1), p. 159165.

4. DANESHVAR M. R. M., BAGHERZADEH A., TAVOUSI T., 2013, Assessment of bioclimatic comfort conditions based on Physiologically Equivalent Temperature (PET) using the RayMan Model in Iran, in: Central European Journal of Geosciences 5(1), p. 53-60.
5. DEMPSEY N., BRAMLEY G., POWER S., BROWN C, 2011, The social dimension of sustainable development: Defining urban social sustainability, in: Sustainable development, 19(5), p. 289-300.

6. FARDPOUR T., 2013, Energy-saving patterns of Iranian Traditional Architecture in various climates, in: Advanced Materials Research 689, p. 66-70.

7. GHAED, S., 2019, The variability and trends of monthly maximum wind speed over Iran, in: IDOJARAS 123(4), p. 521-534.

8. GIVONI B.M., 1976, Climate and architecture, 2nd Edition, Applied science publishers, London.

9. HAZBEI M., ADIB Z., NASROLLAHI F. 2014. Natural ventilation effect on Shavadoons in Dezful by applying CFD modeling, in: Bagh-e Nazar 11(30), p. 43-54.

10. IPCC, 2014, Synthesis report. Contribution of working groups I, II and III to the Fifth Assessment Report of the Intergovernmental Panel on Climate Change, eds. Pachauri R.K., Meyer L.A., IPCC Geneva Switzerland $151 \mathrm{p}$.

11. KHAKI A., SADAT S.A., 2015, Investigating the Effect of Sustainable Patterns of Iran's Traditional Architecture in Sustainable Development, in: European Online Journal of Natural and Social Sciences 3(3), p. 191-208

12. KHODABAKHSHIAN M., MOFIDI S. M., 2013, Advances in underground space development, 13th World Conference of Associated research centers for the urban-underground space (ACUUS), Singapore, p. $478-487$.

13. KHODABAKHSHIAN M., MOFIDI S. M., 2014, Underground Spaces in Arid Climate Architecture of Iran, in: Hoviat Shahr 8(17), p. 35-44.

14. DEHCHESHMEH M. M., GHAEDI S., 2020, Climate Change and Ecological Migration: A Study of Villages in the Province of Khuzestan, Iran, in: Environmental Research, Engineering and Management, 76(1), p. 6-19.

15. RAHMANI E., 2013, Intelligent solutions to the underground spaces in Iran, Advances in underground space development, 13th World conference of associated research centers for the urban-underground space (ACUUS), Singapore, p. 83-94, https://www. acuus.org.

16. REDDY P., 2003, Going underground a Cumbrian perspective. Technology, UK.

17. RONKA K., RITOLA J., RAUHALA K., 1998, Underground space in land-use planning, in: Tunnelling and Underground Space Technology, 13(1), p. 39-49.

18. ROSHAN G., YOUSEFI R., BEAŻEJCZYK K., 2018, Assessment of the climatic potential for tourism in Iran through biometeorology clustering, in: International journal of biometeorology, 62(4), p. 525542.

19. SADOOGHI A., CH. KIBERT F., MIRMOHAMMAD S., JAFARI S., 2019, Thermal performance analysis of a traditional passive cooling system in Dezful, Iran, in: Tunnelling and Underground Space Technology 83(3), p. 291-302.

20. SCHELL L.M., GALLO M.V., RAVENSCROFT J., 2009, Environmental influences on human growth and development: historical review and case study of contemporary influences, in: Ann Hum Biol., 36(5), p. 459-77.

21. SOBCŻYK W., 2015, Sustainable development of Middle East Region, in: Problemy Ekorozwoju/ Problems of sustainable development, 10(2), p. 51-62.

22. SOFLAEI F., SHOKOUHIAN M., SOFLAEI A., 2017, Traditional courtyard houses as a model for sustainable design: A case study on BWhs mesoclimate of Iran, in: Frontiers of Architectural Research 6(3), p. 329-345.

23. VANOS J., WARLAND J., GILLESPIE T., KENNY N., 2010, Review of the physiology of human thermal comfort while exercising in urban landscapes and implications for bioclimatic design, in: Int. J Biometeorol. 54, p. 319-334.

24. WILLIAMS K., BURTON E., JENKS M., 2000, Achieving sustainable urban form: an introduction, in: Achieving sustainable urban form, 2, p. 1-5. 